\title{
Outbreaks by canopy-feeding geometrid moth cause state-dependent shifts in understorey plant communities
}

\author{
Stein Rune Karlsen · Jane Uhd Jepsen • \\ Arvid Odland • Rolf Anker Ims • Arve Elvebakk
}

Received: 29 May 2012/ Accepted: 21 March 2013/Published online: 9 April 2013

(C) The Author(s) 2013. This article is published with open access at Springerlink.com

\begin{abstract}
The increased spread of insect outbreaks is among the most severe impacts of climate warming predicted for northern boreal forest ecosystems. Compound disturbances by insect herbivores can cause sharp transitions between vegetation states with implications for ecosystem productivity and climate feedbacks. By analysing vegetation plots prior to and immediately after a severe and widespread outbreak by geometrid moths in the birch forest-tundra ecotone, we document a shift in forest understorey community composition in response to the moth outbreak. Prior to the moth outbreak, the plots divided into two oligotrophic and one eutrophic plant community. The moth outbreak caused a vegetation state shift in the two oligotrophic communities, but only minor changes in the
\end{abstract}

Communicated by Christian Koerner.

Electronic supplementary material The online version of this article (doi:10.1007/s00442-013-2648-1) contains supplementary material, which is available to authorized users.

S. R. Karlsen $(\bowtie)$

Norut, Northern Research Institute Troms $\varnothing$, Troms $\emptyset$ Science

Park, P.O. Box 6434, 9294 Troms $\varnothing$, Norway

e-mail: stein-rune.karlsen@ norut.no

J. U. Jepsen

Norwegian Institute for Nature Research, 9296 Troms $\varnothing$, Norway

A. Odland

Telemark University College, 3800 B $\varnothing$, Norway

R. A. Ims

Department of Arctic and Marine Biology,

University of Troms $\varnothing, 9294$ Troms $\emptyset$, Norway

A. Elvebakk

Tromsø University Museum, University of Troms $\varnothing$,

9037 Troms $\varnothing$, Norway eutrophic community. In the spatially most widespread communities, oligotrophic dwarf shrub birch forest, dominance by the allelopathic dwarf shrub Empetrum nigrum ssp. hermaphroditum, was effectively broken and replaced by a community dominated by the graminoid Avenella flexuosa, in a manner qualitatively similar to the effect of wild fires in E. nigrum communities in coniferous boreal forest further south. As dominance by E. nigrum is associated with retrogressive succession the observed vegetation state shift has widespread implications for ecosystem productivity on a regional scale. Our findings reveal that the impact of moth outbreaks on the northern boreal birch forest system is highly initial-state dependent, and that the widespread oligotrophic communities have a low resistance to such disturbances. This provides a case for the notion that climate impacts on arctic and northern boreal vegetation may take place most abruptly when conveyed by changed dynamics of irruptive herbivores.

Keywords Plant-herbivore interaction - Empetrum nigrum - Avenella flexuosa $\cdot$ Birch · Tundra-forest ecotone

\section{Introduction}

Top-down trophic control of vegetation by herbivores can effectively change the state of the vegetation and cause dramatic shifts between alternative dynamic regimes (Scheffer and Carpenter 2003; Schmitz 2004; Schmitz et al. 2006). Grazing and trampling by large and medium-sized herbivores change ecosystem functioning by affecting the soil biota (Sørensen et al. 2009), nutrient cycling and availability (Stark et al. 2003; Olofsson et al. 2004) and plant abundance and diversity (Manier and Hobbs 2006; Bråthen et al. 2007). In the tundra, for instance, grazing by 
reindeer has been shown to reduce the cover of both ground lichens (van der Wal et al. 2001; den Herder et al. 2003; Johansen and Karlsen 2005) and dwarf shrubs (den Herder et al. 2008; Olofsson et al. 2009) and has been hypothesized to drive predictable step-wise transitions from unproductive lichen-dominated vegetation to more productive moss- and graminoid-dominated vegetation types (Oksanen and Oksanen 2000; Zimov 2005; van der Wal 2006). However, the likelihood of such transitions, and expectations on the specific nature of their trajectories, are likely to be context-dependent. First, spatially heterogeneous edaphic conditions typically shape the initial state of the vegetation in terms of dominant growth forms with different tolerance to herbivory (Proulx and Mazumder 1998; Wookey et al. 2009; Ravolainen et al. 2010; Speed et al. 2010). Thus the resistance of vegetation to herbivore impacts can be expected to be initial-state dependent. Second, herbivore impact differs in mode and strength depending on a multitude of herbivore taxon-specific traits, for instance, determining their population dynamics and food plant preferences.

In contrast to the more sustained impact of grazing by large and medium-sized herbivores, outbreaks by cyclic insect herbivores take the form of rapid, catastrophic disturbance events that can cause sharp transitions between vegetation states. Compound disturbances by insect outbreaks may change, accelerate, or delay successional pathways (McCullough et al. 1998; Shorohova et al. 2009; Man and Rice 2010), leading for instance to an effective rejuvenation of the vegetation. An example of this is epidemic outbreaks by mountain pine beetle in stands of mature lodgepole pine (Pinus contorta), an early successional tree species (Cattelino et al. 1979). Despite inflicting massive mortality in mature stands, the beetle is an important agent in maintaining continued stands of lodgepole pine, as the build-up of dead wood in the forest following beetle attack mediates wild fires, which are a prerequisite for opening the serotinous lodgepole cones, and hence for lodgepole regeneration (Raffa and Berryman 1987; Malmstrom and Raffa 2000). In a different system, however, attacks by the same beetle species is threatening to drive the less-adapted whitebark pine (Pinus albicaulis) to the brink of extinction (Logan et al. 2010), illustrating how top-down effects of insect outbreaks may also invoke regime shifts (Scheffer and Carpenter 2003; Jasinski and Payette 2005) with profound consequences for the entire trophic system (Schmitz et al. 2006; McKinney et al. 2009; Logan et al. 2010; Tomback and Achuff 2010). While such examples of pervasive ecosystem effects of insect outbreaks usually regard insects specialized on certain tree species and thus primary cascades from their direct impacts on the tree layer in forest ecosystems, some boreal outbreaking insects have a more generalized impact that even extend into tundra ecosystems (Post and Pedersen 2008).

In the birch forest-tundra ecotone in northern Fennoscandia, outbreaks by several species of spring-feeding geometrid moth occur at approximately decadal intervals (Tenow 1972), leading to local or regional canopy defoliation of the preferred host tree, mountain birch (Betula pubescens ssp. tortuosa), as well as certain understorey species. Geometrid population outbreaks dominates the natural disturbance regime in the region in the absence of large-scale wild fires, and recurring outbreaks have been documented as far back as historical records go (to the 1860s; Tenow 1972). Hence, the resilience of the mountain birch forest system to moth outbreaks is thought to be high. However, high grazing pressure by large herbivores in the damaged areas can trigger a shift in the state of the vegetation from birch forest to tundra (Kallio and Lehtonen 1973; Lehtonen 1987; Chapin et al. 2004). Moreover, the birch forest geometrids are highly climate sensitive (Bylund 1999) and for that sake their outbreaks have been predicted to become more extensive and/or severe with climatic warming (Callaghan et al. 2004). Recent studies support these predictions (Jepsen et al. 2008, 2011). The most recent (2002-2009) moth outbreak in northern Fennoscandia was of historically unprecedented extent and severity, and is likely to have been accentuated by recent outbreak range expansions of the two moth species involved (Hagen et al. 2007; Jepsen et al. 2008; Post et al. 2009). In the course of the outbreak as much as one third or $10,000 \mathrm{~km}^{2}$ of the birch forest in northern Fennoscandia was affected by severe defoliation in 1 or more years (Jepsen et al. 2009).

While the effect of moth outbreaks on die-back and regeneration of the main host, birch, has received some attention in the past (Lehtonen 1987; Hoogesteger and Karlsson 1992; Lehtonen and Heikkinen 1995; Tenow et al. 2004), vegetation changes in the herb and dwarf shrub layer of the forest floor following moth outbreaks have been poorly documented (but see Lehtonen and YliRekola 1979; Jepsen et al. 2013). Generally, the understorey of northern boreal forest tends to have received less focus than the tree layer despite the fact that their primary productivities are comparable and that ecosystem functions provided by understorey plants is crucial for the integrity of these ecosystems (Nilsson and Wardle 2005). During an outbreak cycle, moth larval density in the canopy may change from barely detectable levels to several hundred larvae per branch (Hogstad 2005; Klemola et al. 2008; Jepsen et al. 2009), causing complete depletion of the birch canopy early in the season (Tenow 1972). Under such circumstances larvae have also been reported to feed on several deciduous understorey species, including dwarf birch Betula nana (Fig. 1) and bilberry 
Vaccinium myrtillus (e.g. Kallio and Lehtonen 1973; Lehtonen and Yli-Rekola 1979). Mass occurrences of larvae can, however, also be expected to dramatically alter the conditions for a number of understorey plant species not affected by direct defoliation, most noticeably by a change in light conditions (as the canopy is reduced), added nutrients (from larvae droppings and decomposing larvae carcasses), and altered recycling of nutrients and reduced root competition (both from root die-back). This in turn can be expected to change the understorey vegetation state through processes that involve the combination of plant resistance to change in biotic interactions (herbivory and interactions between plant species) and abiotic influences (nutrients and light). As these northern birch forests constitute mosaics of different understorey plant communities based on contrasting edaphic conditions (Hämet-Ahti 1963) it could also be expected that the initial vegetation state could mould the impact of insect outbreaks.

a

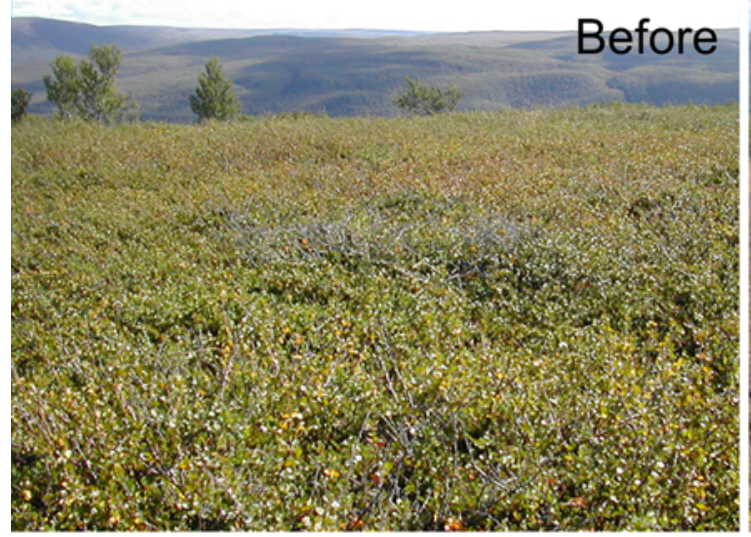

b

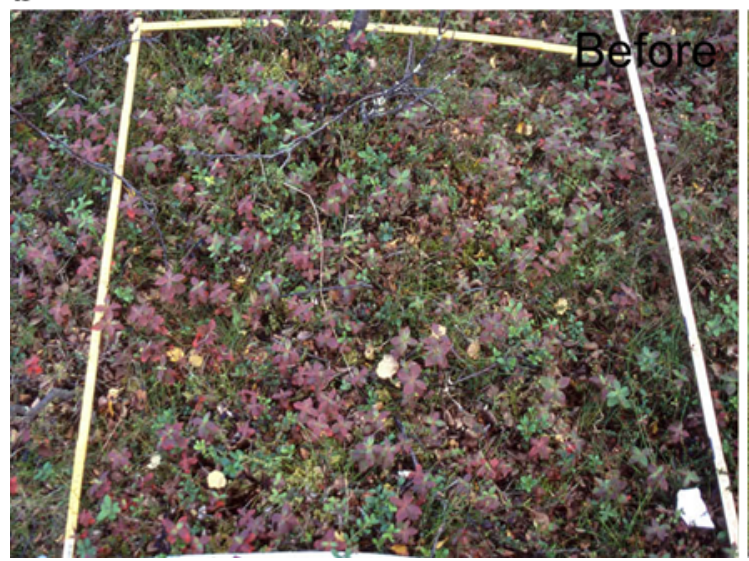

Fig. 1 Photographs illustrating the effects that a severe outbreak of geometrid moth may have on birch forest plant communities. a Betula nana-dominated open heath site located immediately above the tree line before (16 August 2002) and after (22 August 2006) the moth
In the current study we investigate the changes in understorey vegetation following the most recent outbreak by birch forest geometrid moth in northern Fennoscandia. We focus our study on the Varanger Peninsula in northern Norway which is located in the birch forest-tundra ecotone and encompass the north-eastern periphery of the outbreak zone. Incidentally, a quantitative survey of the understorey vegetation had been undertaken the year before the outbreak commenced. This initial survey encompassed sites both within and outside the geometrid outbreak area, which we could exploit by re-surveying these sites towards the end of the outbreak period 4-5 years later to provide a powerful assessment of the impact of the outbreak. The specific objectives of our study were to: (1) determine if moth outbreaks caused a shift in birch forest understorey community composition, (2) determine the extent to which such shifts in community composition were dependent on the state of the community prior to the outbreak, and (3) determine whether indirect effects of the moth outbreak
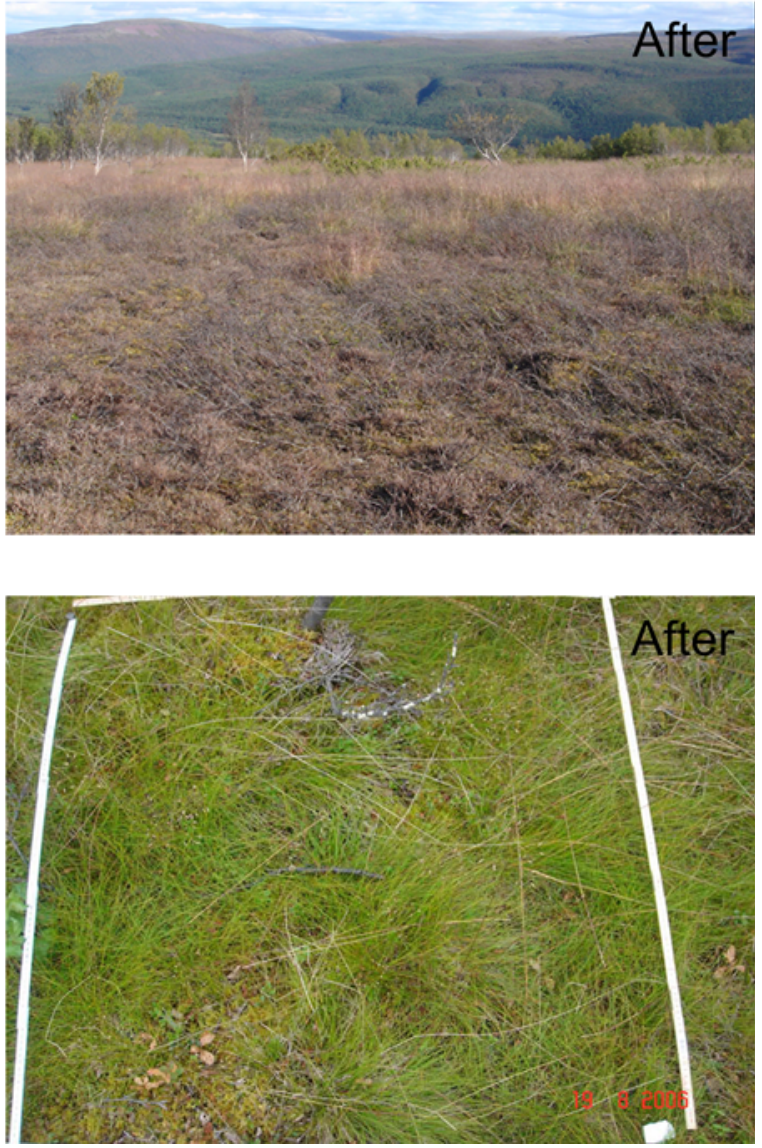

outbreak. b Chamaepericlymenum suecicum-dominated forest plot before (29 August 2002) and after (19 August 2006) the moth outbreak 
could be detected through changes in abundances of nonhost plant species.

\section{Materials and methods}

\section{Study region}

The study was conducted in four areas situated on the Varanger Peninsula, which is the north-easternmost part of mainland Norway, between $70-71^{\circ} \mathrm{N}$ and $28-31^{\circ} \mathrm{E}$. The peninsula is located in the arctic-boreal transition zone (Elvebakk et al. 1999; Karlsen et al. 2005) with a mean July temperature ranging from about $10^{\circ} \mathrm{C}$ at the northeastern coast to above $12{ }^{\circ} \mathrm{C}$ in the south-western interior, and where the annual precipitation is in the range 356-660 mm (www.met.no). The length of the growing season, defined as the period from onset of leafing of birch to $50 \%$ yellowing of leaves of birch, is between 100 and 120 days (Karlsen et al. 2008, 2009). The bedrock geology of the peninsula consists of sedimentary rocks of the Late Proterozoic to Early Cambrian age (Siedlecka and Roberts 1992; Sochava and Siedlecka 1997), which creates a variety of nutrient conditions. Birch (Betula pubescens) is the dominant tree species, and covers large areas in the south-western parts of the peninsula, as well as in protected valleys in northern and eastern parts. On dry and nutrientpoor ground a birch forest type occurs which is characterized by dominance of Empetrum nigrum ssp. hermaphroditum, Vaccinium myrtillus and Chamaepericlymenum suecicum in the field layer, and on slightly more mesic ground E. nigrum becomes less pronounced (Hämet-Ahti 1963; Virtanen et al. 1999; Karlsen et al. 2005). A variety of a more nutrient-demanding herb-rich birch forest type occurs in a more scattered manner, while on the driest and most oligotrophic sites E. nigrum-lichen (Cladina spp.)dominated forest types occur. Riparian forests, characterized by Salix spp. dominance in the tree and shrub layer, and a highly variable field layer, can be common locally along rivers.

Moth outbreak history in the study region

Recurring population outbreaks by the two geometrids, autumnal moth (Epirrita autumnata Bkh.) and winter moth (Operophtera brumata L.), dominate the natural disturbance regime in the Fennoscandian birch forest. Both moth species exhibit cyclic population outbreaks at approximately 10-year intervals in this region (Tenow 1972; Bylund 1999; Neuvonen et al. 1999). The cyclicity of the outbreaks is documented in qualitative historical records as far back as the 1860s (Tenow 1972; Nilssen et al. 2007). The outbreaks can be massive and cause severe defoliation over vast areas and occasionally death of the forest (Tenow 1972; Lehtonen and Heikkinen 1995; Tenow and Bylund 2000). Birch is the main host tree of both moth species in the region, but both winter moth and autumnal moth are reported to occur on a variety of host plants within their distribution ranges (Tenow 1972 and references therein). In the birch forest of Northern Fennoscandia other canopyforming species such as the sparsely occurring Sorbus aucuparia and Salix sp. may also be defoliated when larval densities are high (Tenow 1972; Kallio and Lehtonen 1973). Similarly several understorey dwarf shrub species, in particular B. nana (Fig. 1), V. myrtillus and occasionally Vaccinium uligonosum may be defoliated by the larvae (Kallio and Lehtonen 1973). In parts of its distribution range (e.g. the UK) the winter moth utilizes both coniferous species such as sitka spruce (Picea sitchensis) and common heather (Calluna vulgaris) (Vanbergen et al. 2003). E. nigrum, however, has to the best of our knowledge never been reported as a potential host plant for either moth species.

The most current (2002-2009) outbreak cycle has been of historically unprecedented severity in northernmost Fennoscandia, and the Varanger Peninsula is the region most severely affected. A climate-mediated northeastern expansion in the outbreak range of winter moth (Jepsen et al. 2008) is thought to be part of the explanation. While the Varanger region historically has suffered outbreaks by autumnal moth, the most current outbreak involved both species with a 1- to 2-year lag between population peaks. As a result, many areas in the southern part of the Varanger Peninsula were first defoliated by autumnal moth (2002-2004) and subsequently by winter moth (2005-2006). This pattern has been documented in both field records of larval densities (Klemola et al. 2008) and by mapping of crown defoliation using remote sensing (Jepsen et al. 2009).

\section{Field vegetation surveys}

Field vegetation surveys were done before (2001-2002) (Karlsen et al. 2004, 2005) and after (2006-2007) the geometrid moth outbreak following a hierarchical design. Four study areas with contrasting outbreak history were used: Austertana $\left(70^{\circ} 27^{\prime \prime} \mathrm{N}, 28^{\circ} 35^{\prime \prime} \mathrm{E}\right)$ had a continuous outbreak from 2003 to 2006 , with a peak in the extent of defoliation in 2004, while Klubbvik $\left(70^{\circ} 8^{\prime \prime} \mathrm{N}, 2^{\circ} 7^{\prime \prime} \mathrm{E}\right)$ experienced two peaks in defoliation, in 2003 (autumnal moth) and 2005-2006 (winter moth). The remaining two areas, which are located in forest patches beyond (Båtsfjord, $70^{\circ} 35^{\prime \prime} \mathrm{N}, 29^{\circ} 39^{\prime \prime} \mathrm{E}$ ) or at the periphery (Vads $\varnothing$, $70^{\circ} 4^{\prime \prime} \mathrm{N}, 29^{\circ} 50^{\prime \prime} \mathrm{E}$ ) of the continuous forest zone, were virtually unaffected by the outbreak and serve as references. A total of 18 sites were subjectively selected in 
homogeneous birch forest within the four study areas (two to six sites per area). Within each site, from three to 13 sample plots, each $1 \times 1 \mathrm{~m}$, were randomly allocated in an approximately $5 \times 5-\mathrm{m}$ area. The number of sample plots per site depended on the species diversity of the vegetation with fewer plots allocated to more homogeneous sites. The cover abundance of living parts of each plant species in each sample plot was determined by visual estimates by the same observer (S. R. K.) both before and after the geometrid outbreak. All surveys were done in mid to late August to ensure comparable species cover. Each site was photographed and its position determined by global positioning system, and some plots were further permanently marked with galvanized iron bolts. This allowed an accurate relocation after the outbreak. The nomenclature follows Lid and Lid (2005) for vascular plants.

\section{Data analyses}

The cover abundances of all species were organized in a plot by species matrix where each row represented a plot in a given period (Before or After the outbreak). Each plot further had associated information indicating the treatment (Reference or Outbreak depending on whether the plot was located outside or inside the outbreak range). Plant community associations prior to the outbreak (e.g. the initial states) were identified using hierarchical clustering. We used Ward's linkage function and Morisita-Horn dissimilarities of the non-transformed cover abundance obtained before the outbreak [function hclust() in the $\mathrm{R}$ library stats]. The most likely number of clusters was determined by calculating a number of commonly used cluster-validation measures using cluster.stats() in the R library fpc. Most validation estimates, including the mean silhouette width and the Calinski-Harabasz index, suggested that two clusters was a suitable choice (Fig. 2), while others, including the ratio between the average distance within and between clusters (Fig. 2; WB ratio) suggested that the difference between a two-cluster and a three-cluster solution was very small. Consequently, we address both a twocluster and a three-cluster solution in our analysis.

To identify the significant indicator species for each of the plant communities resulting from the cluster analysis, and to be able to interpret these groups in an ecological context, we performed indicator species analysis (Dufrêne and Legendre 1997) using indval() in R library vegan. Differences in community composition between the plant communities were analysed using the multi-response permutation procedure (MRPP), which is a non-parametric method for testing differences in assembly structure between a priori defined groups. Based on a dissimilarity matrix (here Morisita-Horn), MRPP calculates the observed mean within-group distance weighted by group

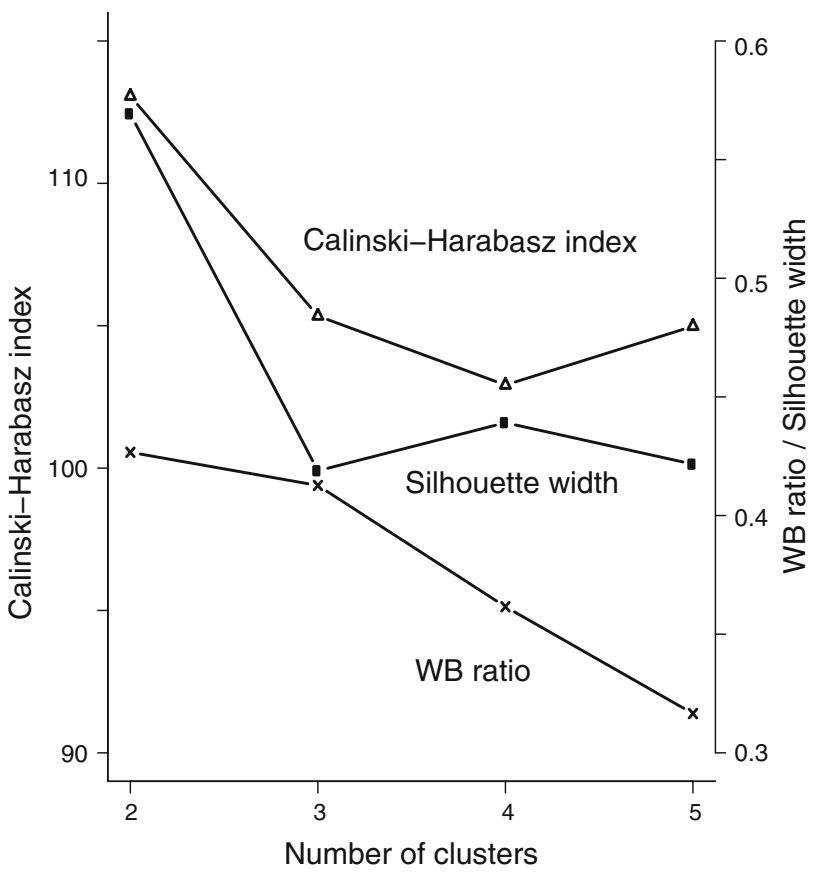

Fig. 2 The values of a selection of cluster-validation measures inspected in order to determine the most suitable number of clusters in the dataset. The Calinski-Harabasz index and the mean silhouette width of clusters suggested that two clusters would be a suitable choice, while the ratio between the average distance within and between clusters (WB ratio) would suggest that there was little difference between a solution based on two and three clusters

sample size (observed $\delta$ ) and the expected mean withingroup distance (expected $\delta$ ) based on Monte-Carlo permutation. The effect size $(A)$, also referred to as the chance-corrected within-group agreement, is expressed as $A=1$-(observed $\delta /$ expected $\delta)$. To visualize the change in each of the plant communities between periods (e.g. in response to the moth outbreak) we used non-metric multidimensional scaling (NMDS) ordination based on Morisita-Horn dissimilarities. NMDS was performed with multiple random starts to find the best global solution using the function metaMDS() in R library vegan. We used a three-dimensional solution since this resulted in a lower stress value (stress 0.09) than a two-dimensional solution (stress 0.14). The point configurations in the two-dimensional and three-dimensional solutions were, however, very similar. MRPP was used to test the significance of the observed shifts in plant communities between periods. To further investigate the significance of the shift in plant communities between periods and treatments we tested the impact of period (before or after the outbreak), treatment (reference or outbreak plot) and the period $\times$ treatment interaction using NMDS plot scores on each of the three ordination axis as response variables. For this we used linear mixed-effect models (LMEs) which allows for including random effects to control for autocorrelation in 
the data caused by nested designs. In our case the 92 plots were nested within 18 different sites, and we consequently included site as a random effect in both models. We specifically looked for significant period $\times$ treatment interactions which would indicate that outbreak plots were affected differently than reference plots by the moth outbreak. LMEs were developed using glmmadmb() in $\mathrm{R}$ library glmmADMB.

\section{Results}

Classification and characterization of initial plant community states

Hierarchical clustering of the vegetation community data using two clusters resulted in clusters containing 64 and 28 plots, respectively. The strongest indicator species for the first division of the dendrogram (e.g. into two clusters; Table 1) were $V$. myrtillus, E. nigrum and $C$. suecicum (cluster 1) and Ranunculus acris, Geranium sylvaticum and Solidago virgaurea (cluster 2), suggesting that this division separates a poorer dwarf shrub community (cluster 1) from a richer herb-rich community (cluster 2). Clustering using three clusters subdivided cluster 1 into two clusters (clusters 1.1 and 1.2; Table 1) containing 30 and 34 plots, respectively. The list of significant indicator species suggests that clusters 1.1 and 1.2 both represent dwarf shrubdominated birch forest types, but cluster 1.1 is indicated most strongly by E. nigrum, suggesting a more nutrientpoor and/or drier community than cluster 1.2 , which is indicated by $V$. myrtillus and $C$. suecicum (see Table 1 for a full list). V. myrtillus and C. suecicum also have relatively high indicator values for cluster 1.1, which is hence best described as a "crowberry-bilberry-dwarf cornel" type (henceforth "crowberry birch forest"). Cluster 1.2 is best described as a "bilberry-dwarf cornel" type (henceforth "bilberry birch forest"). Cluster 2 represents a herb- and grass-dominated birch forest type with a richer plant community and large number of significant indicator species identified (Table 1). In the following we term cluster 2 "low-herb birch forest". A complementary description of the three plant communities is available in Online Resource 1 in the Electronic Supplementary Material. The three communities differed in community composition (MRPP for difference between clusters, $A=0.482, P<0.001$ ).

Moth outbreak-induced shifts in community composition and species abundances

The understorey community composition shifted markedly in response to the moth outbreak (MRPP for difference between periods, all plots, $A=0.066, P<0.001$; outbreak plots only, $A=0.16, P<0.001)$. Based on the NMDS ordination (Fig. 3), it is clear that not all communities contributed to this shift, showing that plant community resistance to moth outbreaks differed widely depending on the initial state of the vegetation. Plots located in the two more oligotrophic dwarf shrub communities showed large and directed shifts primarily along the 2 nd axis, while plots in the more eutrophic low-herb community, showed much smaller, non-directional shifts of a similar magnitude to the reference plots (Fig. 3). Linear mixed-effects models developed using the NMDS ordination scores as response variables and site as a random effect (Fig. 4) confirm that community changes in response to the outbreak differs between outbreak and reference plots, as indicated by highly significant period $\times$ treatment interactions for all three ordination axis (NMDS1 $, \quad z=5.54, \quad P<0.001 ; \quad$ NMDS2,$\quad z=6.92$, $P<0.001$; NMDS3, $z=5.60, P<0.001$ ).

The significant shifts in understorey community composition observed in the two oligotrophic communities were mainly due to large changes in abundance of a limited number of plant species (Fig. 5). The two oligotrophic communities experienced a drastic transition from dominance by dwarf shrubs (V. myrtillus, B. nana and E. nigrum) to dominance by the grass A. flexuosa. In addition, the low herb $C$. suecicum experienced a large decrease in cover in both communities (Fig. 5a, b). C. suecicum is defoliated by larvae at outbreak densities (authors' observations). None of the species in the eutrophic community (Fig. 5c) showed significant changes in abundance in response to the moth outbreak.

\section{Discussion}

Owing to the incidental, but fortunate, spatially extensive vegetation survey (Karlsen et al. 2004, 2005) conducted just prior to the onset of one of the most severe and largescale insect outbreak recorded across the circumpolar forest-tundra ecotone (Post et al. 2009), we could apply a quasi-experimental approach to assess some crucial aspects of the impact of the outbreak. In particular, these circumstances allowed us to demonstrate the magnitude of the impact on community composition and individual plant species abundances, and how the impact was dependent on the initial state of the vegetation. Previous studies have reported changes in understorey plant species abundance during the years following geometrid moth outbreaks without knowledge of pre-outbreak abundances (Kallio and Lehtonen 1973; Lehtonen and Yli-Rekola 1979). The setting of the present study, however, allowed for a direct quantitative assessment and inferences about which factors make the vegetation more or less resistant to massive disturbances of this kind. 
Table 1 Indicator values for all species that are significant indicators of the plant communities identified by hierarchical clustering

\begin{tabular}{|c|c|c|c|c|c|}
\hline \multirow[t]{2}{*}{ Species } & \multicolumn{2}{|c|}{ Two clusters } & \multicolumn{3}{|c|}{ Three clusters } \\
\hline & Cluster 1 & Cluster 2 & Cluster 1.1 & Cluster 1.2 & Cluster 2 \\
\hline Alchemilla glomerulans & 0 & $0.357^{\mathrm{a}}$ & 0 & 0 & $0.357^{\mathrm{a}}$ \\
\hline Anthoxanthum nipponicum & 0 & $0.781^{\mathrm{a}}$ & 0 & 0 & $0.776^{\mathrm{a}}$ \\
\hline Astragalus alpinus & 0 & $0.321^{\mathrm{a}}$ & 0 & 0 & $0.321^{\mathrm{a}}$ \\
\hline Bryophytes & $0.558^{\mathrm{a}}$ & 0.349 & $0.556^{\mathrm{a}}$ & 0.174 & 0.209 \\
\hline Bistorta vivipara & 0 & $0.786^{\mathrm{a}}$ & 0 & 0 & $0.786^{\mathrm{a}}$ \\
\hline Cerastium fontanum & 0 & $0.464^{\mathrm{a}}$ & 0 & 0 & $0.464^{\mathrm{a}}$ \\
\hline Cirsium heterophyllum & 0 & $0.143^{\mathrm{a}}$ & 0 & 0 & $0.143^{\mathrm{a}}$ \\
\hline Calamagrostis phragmitoides & 0 & $0.286^{\mathrm{a}}$ & 0 & 0 & 0.286 \\
\hline Chamaepericlymenum suecicum & $0.878^{\mathrm{a}}$ & 0.041 & 0.296 & $0.625^{\mathrm{a}}$ & 0.022 \\
\hline Empetrum nigrum & $0.824^{\mathrm{a}}$ & 0.007 & $0.800^{\mathrm{a}}$ & 0.133 & 0.003 \\
\hline Equisetum pratense & n.s. & n.s. & 0 & $0.147^{\mathrm{a}}$ & 0 \\
\hline Festuca rubra & 0 & $0.566^{\mathrm{a}}$ & 0 & 0.001 & $0.562^{\mathrm{a}}$ \\
\hline Filipendula ulmaria & 0 & $0.179^{\mathrm{a}}$ & 0 & 0 & $0.179^{\mathrm{a}}$ \\
\hline Geum rivale & 0 & $0.214^{\mathrm{a}}$ & 0 & 0 & $0.214^{\mathrm{a}}$ \\
\hline Geranium sylvaticum & 0 & 0.999 & 0 & 0 & $0.998^{\mathrm{a}}$ \\
\hline Hieracium sp. & 0.001 & $0.520^{\mathrm{a}}$ & 0 & 0.003 & $0.507^{\mathrm{a}}$ \\
\hline Lycopodium annotinum & 0 & $0.143^{\mathrm{a}}$ & 0 & 0 & $0.143^{\mathrm{a}}$ \\
\hline Linnea borealis & $0.188^{\mathrm{a}}$ & 0 & $0.174^{\mathrm{a}}$ & 0.041 & 0 \\
\hline Luzula pilosa & 0.016 & $0.400^{\mathrm{a}}$ & 0 & 0.046 & $0.327^{\mathrm{a}}$ \\
\hline Melampyrum pratense & $0.281^{\mathrm{a}}$ & 0 & 0.071 & $0.227^{\mathrm{a}}$ & 0 \\
\hline Orthilia secunda & 0 & $0.321^{\mathrm{a}}$ & 0 & 0 & $0.321^{\mathrm{a}}$ \\
\hline Pyrola minor & 0 & $0.607^{\mathrm{a}}$ & 0 & 0 & $0.607^{\mathrm{a}}$ \\
\hline Parnassia palustris & 0 & $0.214^{\mathrm{a}}$ & 0 & 0 & $0.214^{\mathrm{a}}$ \\
\hline Rumex acetosa & 0.001 & $0.169^{\mathrm{a}}$ & 0 & 0.003 & $0.162^{\mathrm{a}}$ \\
\hline Ranunculus acris & 0 & $1.000^{\mathrm{a}}$ & 0 & 0 & $1.000^{\mathrm{a}}$ \\
\hline Rubus saxatilis & 0 & $0.643^{\mathrm{a}}$ & 0 & 0 & $0.643^{\mathrm{a}}$ \\
\hline Saussurea alpina & 0 & $0.143^{\mathrm{a}}$ & 0 & 0 & $0.143^{\mathrm{a}}$ \\
\hline Salix glauca & 0 & $0.107^{\mathrm{a}}$ & 0 & 0 & $0.107^{\mathrm{a}}$ \\
\hline Selaginella selaginoides & 0 & $0.286^{\mathrm{a}}$ & 0 & 0 & $0.286^{\mathrm{a}}$ \\
\hline Solidago virgaurea & 0.002 & $0.963^{\mathrm{a}}$ & 0.003 & 0.002 & $0.928^{\mathrm{a}}$ \\
\hline Trientalis europaea & 0.001 & $0.170^{\mathrm{a}}$ & 0 & 0.002 & $0.164^{\mathrm{a}}$ \\
\hline Trollius europaeus & 0 & $0.286^{\mathrm{a}}$ & 0 & 0 & $0.286^{\mathrm{a}}$ \\
\hline Viola biflora & 0 & $0.964^{\mathrm{a}}$ & 0 & 0 & $0.964^{\mathrm{a}}$ \\
\hline Vaccinium myrtillus & $0.886^{\mathrm{a}}$ & 0.046 & 0.323 & $0.608^{\mathrm{a}}$ & 0.024 \\
\hline
\end{tabular}

Results are shown for a two-cluster solution and a three-cluster solution

${ }^{\text {a }}$ Highest indicator value per species

In general we found that the compound disturbances inflicted by the geometrids that defoliated the tree layer also caused major changes in the understorey vegetation. The nature and magnitude of these changes were, however, conditional on the initial state of the vegetation according to dominant growth forms (dwarf shrubs or herbs) and/or nutrient status (oligotrophic or eutrophic). The impact of the moth outbreak in the two oligotrophic dwarf shrub communities initially dominated by dwarf shrubs caused significant shifts along the main floristic gradients that ought to be characterized as a vegetation state shift. In the eutrophic community, by comparison, the change was negligible. Our results corroborate the findings of a recent study (Jepsen et al. 2013) which addressed the cascading effects of moth defoliation on plant and herbivore communities on a regional scale in northern Norway. Without knowledge of plant or herbivore abundances prior to the outbreak, the authors relied on regional contrast in defoliation severity to demonstrate a relationship between increased defoliation and increased abundance of grasses (in particular A. flexuosa) and decreased abundances of dwarf shrubs (in particular E. nigrum) in addition to 

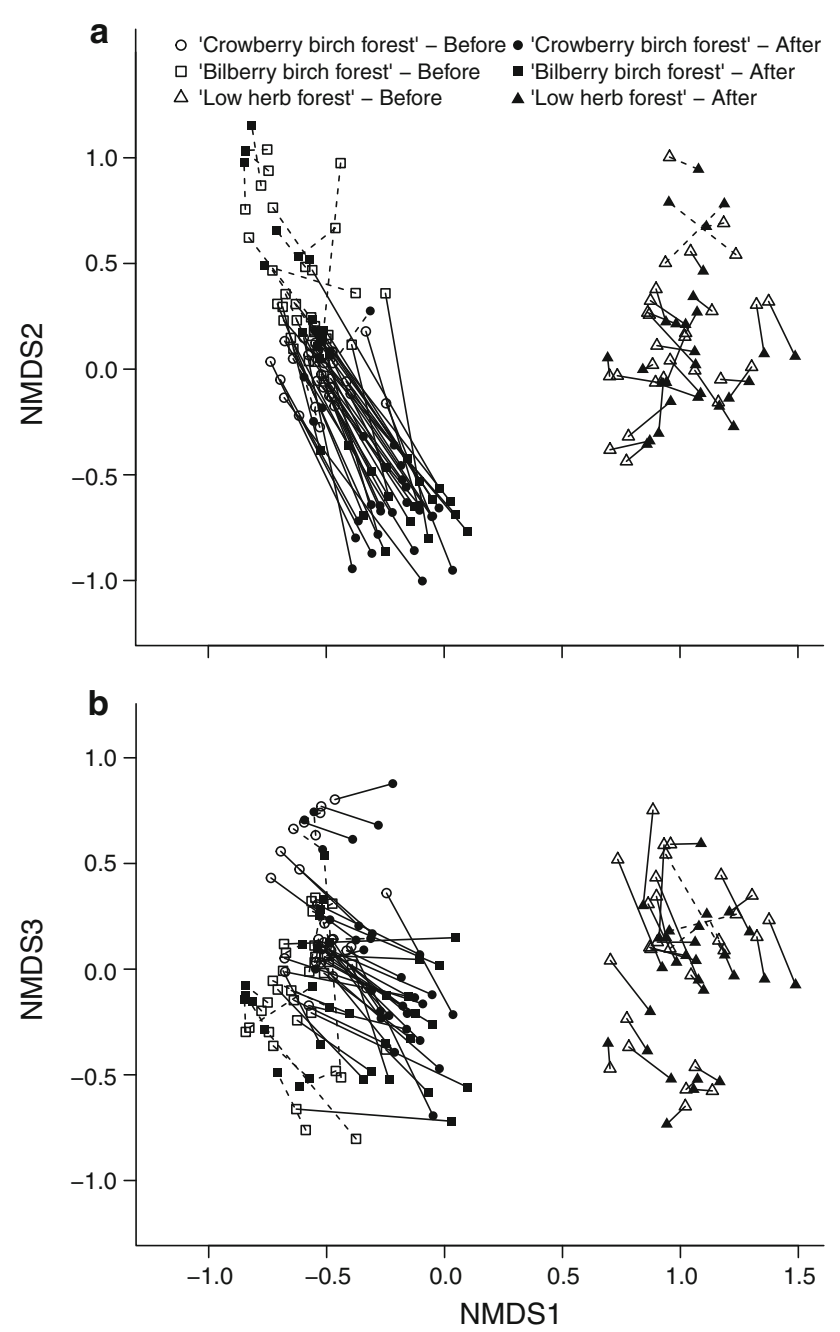

Fig. 3 Nonmetric multidimensional scaling (NMDS) ordination of the 92 plots before (open symbols) and after (closed symbols) the moth outbreak. While the two dwarf shrub communities show marked shifts along the 2 nd axis, the low-herb community shows only nondirectional shifts in the same magnitude as the reference plots. Black lines connect the before-after ordination scores of plots located within the outbreak range, while dotted lines connect the before-after score of reference plots located outside the outbreak range. Stress value of the three-dimensional solution: 0.14

significant cascading effects on the herbivore community. The results of the current study demonstrate with all clarity that the patterns inferred by Jepsen et al. (2013) from regional spatial contrasts are founded on actual temporal transitions from dwarf shrub dominance to grassland on a local scale.

The two dwarf shrub communities suffered an almost complete loss of live dwarf shrubs after the moth outbreak. Thus the low resistance of the woody growth forms in the field layer mirrors that of the birch in the tree layer, as the majority of the birch trees do not survive such intensive and long-lasting defoliation (Tenow 1972). Although birch is the main host plant for the two geometrid moth species in

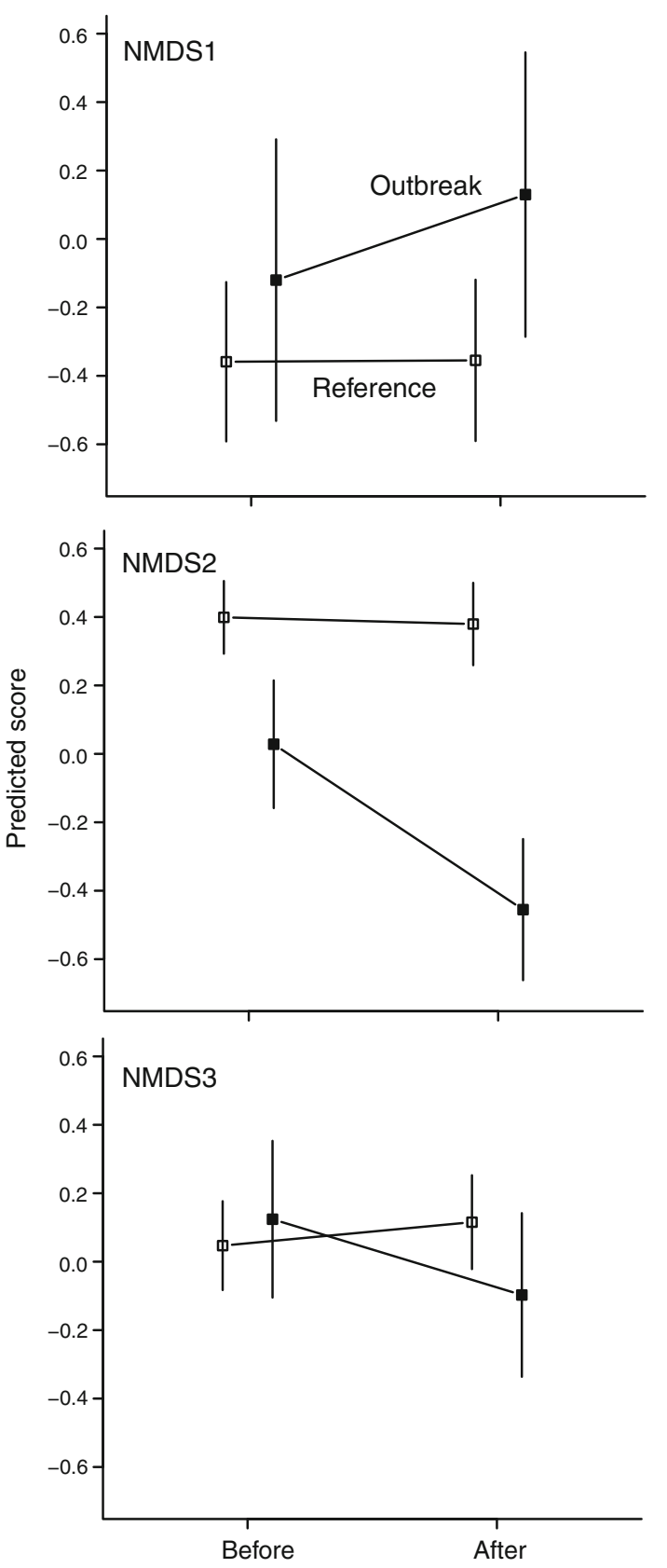

Fig. 4 Linear mixed-effect model predictions with SEs for the moth outbreak-induced shift in community composition along the three NMDS ordination axes (NMDS1-3) for outbreak (filled symbols) and reference (open symbols) plots

question, moth larvae also defoliate deciduous dwarf shrub species such as $B$. nana and $V$. myrtillus during mass outbreaks (Kallio and Lehtonen 1973; Lehtonen and YliRekola 1979; Fig. 1). However, E. nigrum which is generally unpalatable to herbivores (Bråthen et al. 2007), appears not be defoliated (Kallio and Lehtonen 1973; Online Resource 2). Hence, the extensive mortality of this evergreen remains something of an enigma that deserves further, probably experimental, investigation. Although 

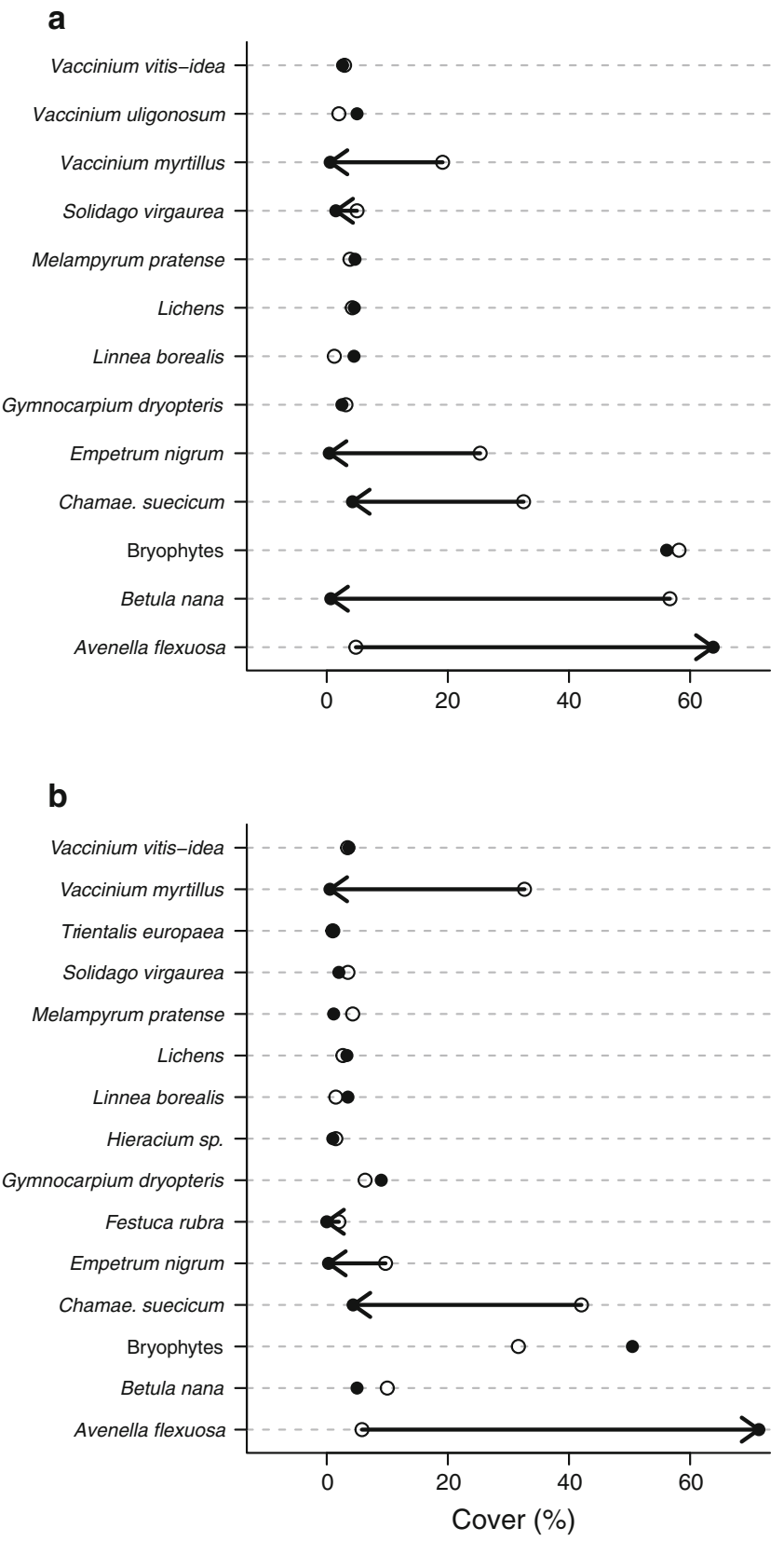

Fig. 5 The cover abundance of individual species before (open symbols) and after (closed symbols) the moth outbreak. Cover abundances are given as mean for all plots in which a given species is present within a given community. a Crowberry birch forest,

deciduous species are the favoured hosts, larvae of both species have been reported to defoliate evergreen trees (Tenow 1972), and winter moth can reach outbreak densities on sitka spruce and common heather (Vanbergen et al. 2003). Although no obvious foliage loss is evident in E. nigrum during mass outbreaks, a possibility is that starving larvae attempt to eat the leaves (e.g. punctuate them without causing visible foliage loss), thereby weakening the plant by making it more susceptible to

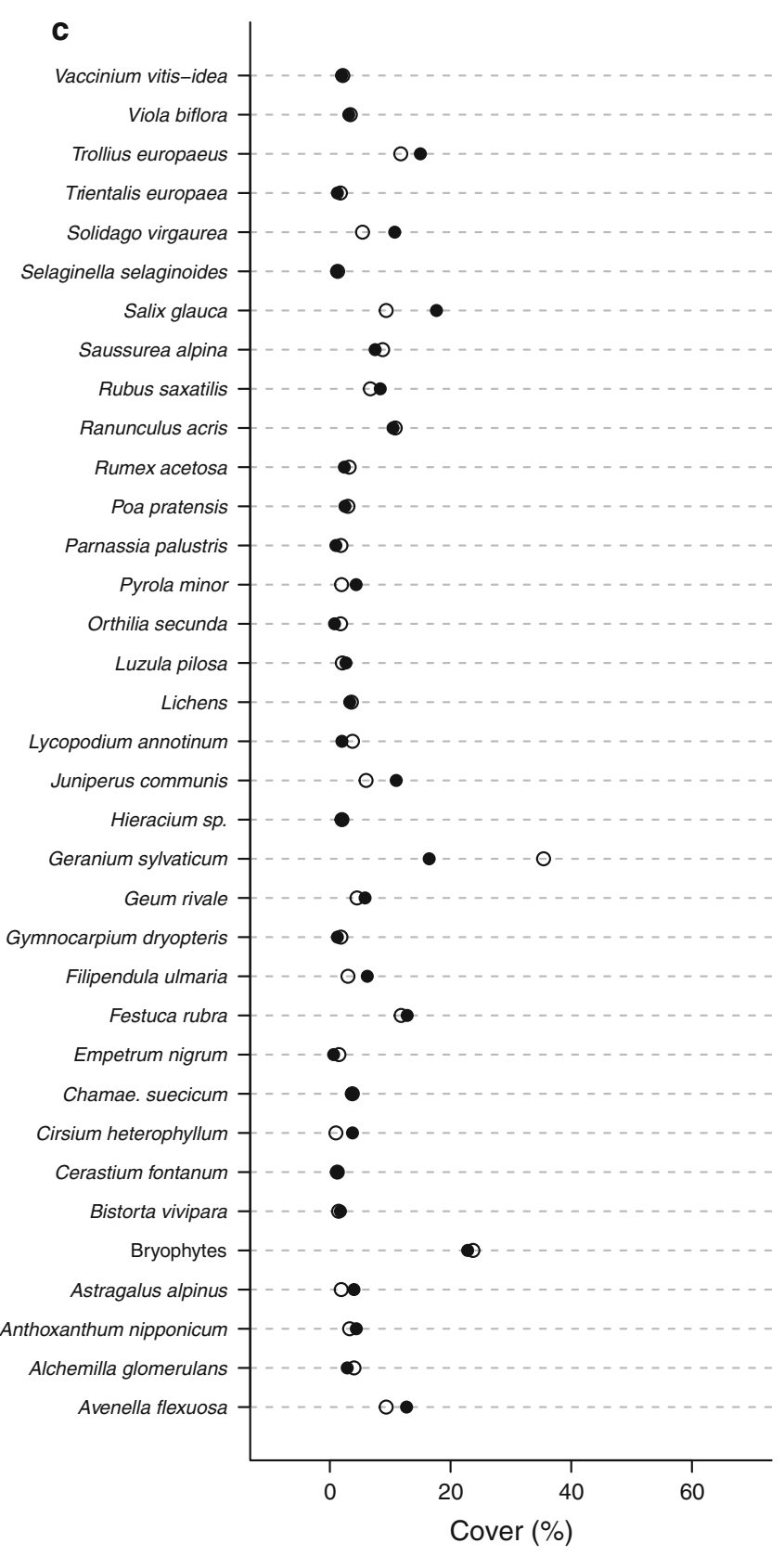

b bilberry birch forest, c low-herb birch forest. Cover abundances with non-overlapping SDs before and after the outbreak are connected by arrows. Chamae. suecicum Chamaepericlymenum suecicum

desiccation or infection by fungal pathogens (Olofsson et al. 2011).

In both dwarf shrub communities A. flexuosa responded positively to the disturbance and came to completely dominate the vegetation (Figs. 1, 5). A. flexuosa is not defoliated by moth larvae and probably became released from limitations of light under canopies of birch shrubs and trees (that became defoliated) and nutrients that became added as larval frass and carcasses to the oligotrophic soil. 
It is also likely that the positive response in A. flexuosa is tightly linked to the loss of shrubs; in particular the allelopathic E. nigrum which often is the dominant of latesuccessional stages of heath and nutrient-poor forest vegetation (Haapaasari 1988; Tybirk et al. 2000; Bråthen et al. 2010). Dominance by E. nigrum is associated with retrogressive succession due to an accumulation of polyphenolic compounds in the soil (Nilsson and Wardle 2005). This in turn adversely affect soil microbial activity, decomposition rates, nutrient availability and hence tree and understorey productivity (Wardle et al. 1997; DeLuca et al. 2002; Wardle et al. 2003; Nilsson and Wardle 2005). In northern boreal coniferous and mixed forests the dominance of E. nigrum is broken by recurrent fires (Zackrisson et al. 1995, 1996), which both remove above-ground plant parts and change soil conditions such as $\mathrm{pH}$, humus layer thickness and nutrient availability. Field experimental studies have confirmed that severe disturbance is needed to break the dominance of E. nigrum, and that the effects of disturbance are enhanced by fertilization (Olofsson et al. 2005; Manninen et al. 2011). We have documented here that severe moth outbreaks effectively break the dominance of E. nigrum in a manner qualitatively similar to wild fires in coniferous forest, albeit on a much larger spatial scale. Dwarf shrub birch forest is, by far, the most common forest type in the Tana-Varanger region where our study areas are located (Hämet-Ahti 1963; Väre 2001; Wielgolaski 2001). It here covers approximately $900 \mathrm{~km}^{2}$ and virtually all of this area was affected by severe defoliation in one or more years during the period 2002-2009 (Jepsen et al. 2009). For comparison, the total forest area affected by wildfires in Norway as a whole during the same period was just above $100 \mathrm{~km}^{2}$ (Directorate for Civil Protection and Emergency Planning, www.dsb.no).

As outlined above, the strength of the response of the initially omnipresent A. flexuosa in the two oligotrophic dwarf shrub communities was likely conditional on a combination of initially low nutrient levels, its own initial abundance and the abundance of the allelopathic E. nigrum. In the initially eutrophic plant community, the response of graminoids (A. flexuosa and $F$. rubra) was either weak or absent. This was most likely because grasses were initially less nutrient limited and/or because of intense competition for space and light with a high diversity of other understorey plants (e.g. forbs) not responding to the moth outbreak. Indeed, the high species diversity of the low-herb forest types may have contributed to the resistance of these communities to disturbance (Hooper et al. 2005).

\section{Conclusion}

The spread of massive outbreaks of folivorous insects has for some time been predicted to become one of the most severe impacts of climate warming on northern boreal forest ecosystems (Neuvonen et al. 1999; Callaghan et al. 2004). In line with these predictions we have now empirically demonstrated the impact of an unprecedented geometrid moth outbreak due to a range expansion of the winter moth that extended across the birch forest-tundra ecotone in northernmost Fennoscandia (Jepsen et al. 2008; Post et al. 2009). We found that the most spatially extensive plant communities in the impacted region, two types of oligotrophic dwarf shrub birch forest, experienced large shifts in community composition and hence had very low resistance to the outbreak. This was apparently due to the initial dominance of woody growth forms (E. nigrum and $V$. myrtillus) that were intolerant to defoliation, and the occurrence of a widespread graminoid that had an initially low abundance, which rapidly gained dominance when nutrients became available from larval excreta and the allelopatric dwarf shrub E. nigrum was eliminated. In effect the vegetation of vast areas was transformed from a shrubdominated state to grassland. Our finding corroborates the notion that high-latitude ecosystems may generally have little resistance to climate-induced species invasions (Callaghan et al. 2004; Ims and Fuglei 2005; Post et al. 2009). In particular, the impact of climate on arctic vegetation may take place most abruptly when conveyed by changed dynamics of herbivores (Ims and Fuglei 2005; Post and Pedersen 2008) or pathogens (Olofsson et al. 2011).

Acknowledgments We thank Martin Biuw for providing statistical advice. Three anonymous reviewers provided recommendations that improved an earlier draft of the manuscript. Financial support was obtained from the Research Council of Norway. This study is an activity under the Nordic Centre of Excellence programme How to preserve the Tundra in a Warming Climate (NCoE-Tundra).

Open Access This article is distributed under the terms of the Creative Commons Attribution License which permits any use, distribution, and reproduction in any medium, provided the original author(s) and the source are credited.

\section{References}

Bråthen KA, Ims RA, Yoccoz NG, Fauchald P, Tveraa T, Hausner VH (2007) Induced shift in ecosystem productivity? Extensive scale effects of abundant large herbivores. Ecosystems 10:773-789

Bråthen KA, Fodstad CH, Gallet C (2010) Ecosystem disturbance reduces the allelopathic effects of Empetrum hermaphroditum humus on tundra plants. J Veg Sci 21:786-795

Bylund H (1999) Climate and the population dynamics of two insect outbreak species in the North. Ecol Bull 47:54-62

Callaghan TV, et al. (2004) Effects on the structure of arctic ecosystems in the short- and long-term perspectives. Ambio 33:436-447

Cattelino PJ, Noble IR, Slatyer RO, Kessell SR (1979) Predicting the multiple pathways of plant succession. Environ Manage 3:41-50 
Chapin FS, et al. (2004) Global change and the boreal forest: thresholds, shifting states or gradual change? Ambio 33:361-365

DeLuca TH, Nilsson MC, Zackrisson O (2002) Nitrogen mineralization and phenol accumulation along a fire chronosequence in northern Sweden. Oecologia 133:206-214

den Herder M, Kytoviita MM, Niemelä P (2003) Growth of reindeer lichens and effects of reindeer grazing on ground cover vegetation in a Scots pine forest and a subarctic heathland in Finnish Lapland. Ecography 26:3-12

den Herder M, Virtanen R, Roininen H (2008) Reindeer herbivory reduces willow growth and grouse forage in a forest-tundra ecotone. Basic Appl Ecol 9:324-331

Dufrêne M, Legendre P (1997) Species assemblages and indicator species: the need for a flexible asymmetrical approach. Ecol Monogr 67:345-366

Elvebakk A, Elven R, Razzhivin VY (1999) Delimitation, zonal and sectorial subdivision of the Arctic for the Panarctic Flora Project. In: Nordal I, Razzhivin VY (eds) The species concept in the high north - a panarctic flora initiative. The Norwegian Academy of Science and Letters, Oslo, pp 375-386

Haapaasari M (1988) The oligotrophic heath vegetation of northern Fennoscandia and its zonation. Acta Bot Fenn 135:1-219

Hagen SB, Jepsen JU, Ims RA, Yoccoz NG (2007) Shifting altitudinal distribution of outbreak zones of winter moth Operophtera brumata in sub-arctic birch forest: a response to recent climate warming? Ecography 30:299-307

Hämet-Ahti L (1963) Zonation of the mountain birch forests in northernmost Fennoscandia. Ann Bot Soc Zool Bot Fenn $34: 1-127$

Hogstad O (2005) Numerical and functional responses of breeding passerine species to mass occurrence of geometrid caterpillars in a subalpine birch forest: a 30-year study. Ibis 147:77-91

Hoogesteger J, Karlsson PS (1992) Effects of defoliation on radial stem growth and photosynthesis in the mountain birch (Betula pubescens ssp. tortuosa). Funct Ecol 6:317-323

Hooper DU, et al. (2005) Effects of biodiversity on ecosystem functioning: a consensus of current knowledge. Ecol Monogr 75:3-35

Ims RA, Fuglei E (2005) Trophic interaction cycles in tundra ecosystems and the impact of climate change. Bioscience 55:311-322

Jasinski JPP, Payette S (2005) The creation of alternative stable states in the southern boreal forest, Quebec, Canada. Ecol Monogr 75:561-583

Jepsen JU, Hagen SB, Ims RA, Yoccoz NG (2008) Climate change and outbreaks of the geometrids Operophtera brumata and Epirrita autumnata in sub-arctic birch forest: evidence of a recent outbreak range expansion. J Anim Ecol 77:257-264

Jepsen JU, et al. (2009) Monitoring the spatio-temporal dynamics of geometrid moth outbreaks in birch forest using MODIS-NDVI data. Remote Sens Environ 113:1939-1947

Jepsen JU, et al. (2011) Rapid northwards expansion of a forest insect pest attributed to spring phenology matching with sub-Arctic birch. Glob Change Biol 17:2071-2083

Jepsen JU, et al. (2013) Ecosystem impacts of a range expanding forest defoliator at the forest-tundra ecotone. Ecosystems Online Early. doi:10.1007/s10021-012-9629-9

Johansen B, Karlsen SR (2005) Monitoring vegetation changes on Finnmarksvidda, Northern Norway, using Landsat MSS and Landsat TM/ETM+ satellite images. Phytocoenologia 35:969-984

Kallio P, Lehtonen J (1973) Birch forest damage caused by Oporina autumnata (Bkh.) in 1966-99 in Utsjoki. Rep Kevo Subarct Res Stn 10

Karlsen SR, Molvig H, Ørjebu A, Sarre AP (2004) Hogst- og beitevurdering av inngjerdinger i bjørkeskog. Klubbvik, Nesseby kommune, Finnmark. Norut IT Rapport IT744/1-2004

Karlsen SR, Elvebakk A, Johansen B (2005) A vegetation-based method to map climatic variation in the arctic-boreal transition area of Finnmark, north-easternmost Norway. J Biogeogr 32:1161-1186

Karlsen SR, et al. (2008) MODIS-NDVI-based mapping of the length of the growing season in northern Fennoscandia. Int J Appl Earth Obs Geoinf 10:253-266

Karlsen SR, et al. (2009) Growing-season trends in Fennoscandia 1982-2006, determined from satellite and phenology data. Climate Res 39:275-286

Klemola T, Andersson T, Ruohomaki K (2008) Fecundity of the autumnal moth depends on pooled geometrid abundance without a time lag: implications for cyclic population dynamics. J Anim Ecol 77:597-604

Lehtonen J (1987) Recovery and development of birch forests damaged by Epirrita autumnata in Utsjoki area, North Finland. Rep Kevo Subarct Res Stn 20

Lehtonen J, Heikkinen RK (1995) On the recovery of mountain birch after Epirrita damage in Finnish Lapland, with a particular emphasis on reindeer grazing. Ecoscience 2:349-356

Lehtonen J, Yli-Rekola M (1979) Field and ground layer vegetation in birch forests after Oporinia damage. Rep Kevo Subarct Res Stn 15:27-32

Lid J, Lid DT (2005) Norsk flora, 7th edn (in Norwegian). Norske Samlaget, Oslo

Logan JA, Macfarlane WW, Willcox L (2010) Whitebark pine vulnerability to climate-driven mountain pine beetle disturbance in the Greater Yellowstone Ecosystem. Ecol Appl 20:895-902

Malmstrom CM, Raffa KF (2000) Biotic disturbance agents in the boreal forest: considerations for vegetation change models. Glob Change Biol 6:35-48

Man RZ, Rice JA (2010) Response of aspen stands to forest tent caterpillar defoliation and subsequent overstory mortality in northeastern Ontario, Canada. For Ecol Manage 260:1853-1860

Manier DJ, Hobbs NT (2006) Large herbivores influence the composition and diversity of shrub-steppe communities in the Rocky Mountains, USA. Oecologia 146:641-651

Manninen OH, Stark S, Kytoviita MM, Tolvanen A (2011) Individual and combined effects of disturbance and $\mathrm{N}$ addition on understorey vegetation in a subarctic mountain birch forest. J Veg Sci 22:262-272

McCullough DG, Werner RA, Neumann D (1998) Fire and insects in northern and boreal forest ecosystems of North America. Annu Rev Entomol 43:107-127

McKinney ST, Fiedler CE, Tomback DF (2009) Invasive pathogen threatens bird-pine mutualism: implications for sustaining a high-elevation ecosystem. Ecol Appl 19:597-607

Neuvonen S, Niemelä P, Virtanen T (1999) Climatic change and insect outbreaks in boreal forest: the role of winter temperatures. Ecol Bull 47:63-67

Nilssen AC, Tenow O, Bylund H (2007) Waves and synchrony in Epirrita autumnata/Operopthera brumata outbreaks. II. Sunspot activity cannot explain cyclic outbreaks. J Anim Ecol 76:269-275

Nilsson MC, Wardle DA (2005) Understory vegetation as a forest ecosystem driver: evidence from the northern Swedish boreal forest. Front Ecol Environ 3:421-428

Oksanen L, Oksanen T (2000) The logic and realism of the hypothesis of exploitation ecosystems. Am Nat 155:703-723

Olofsson J, Stark S, Oksanen L (2004) Reindeer influence on ecosystem processes in the tundra. Oikos 105:386-396

Olofsson J, Hulme PH, Oksanen L, Suominen O (2005) Effects of mammalian herbivores on revegetation of disturbed areas in different locations in the forest-tundra ecotone in northern Fennoscandia. Landsc Ecol 20:351-359

Olofsson J, Oksanen L, Callaghan T, Hulme PE, Oksanen T, Suominen O (2009) Herbivores inhibit climate-driven shrub expansion on the tundra. Glob Change Biol 15:2681-2693 
Olofsson J, Ericson L, Torp M, Stark S, Baxter R (2011) Carbon balance of Arctic tundra under increased snow cover mediated by a plant pathogen. Nat Clim Change 1:220-223

Post E, Pedersen C (2008) Opposing plant community responses to warming with and without herbivores. Proc Natl Acad Sci USA 105:12353-12358

Post E, et al. (2009) Ecological dynamics across the Arctic associated with recent climate change. Science 325:1355-1358

Proulx M, Mazumder A (1998) Reversal of grazing impact on plant species richness in nutrient-poor vs. nutrient-rich ecosystems. Ecology 79:2581-2592

Raffa KF, Berryman AA (1987) Interacting selective pressures in conifer-bark beetle systems - a basis for reciprocal adaptations. Am Nat 129:234-262

Ravolainen VT, Yoccoz NG, Bråthen KA, Ims RA, Iversen M, Gonzalez VT (2010) Additive partitioning of diversity reveals no scale-dependent impacts of large ungulates on the structure of tundra plant communities. Ecosystems 13:157-170

Scheffer M, Carpenter SR (2003) Catastrophic regime shifts in ecosystems: linking theory to observation. Trends Ecol Evol 18:648-656

Schmitz OJ (2004) Perturbation and abrupt shift in trophic control of biodiversity and productivity. Ecol Lett 7:403-409

Schmitz OJ, Kalies EL, Booth MG (2006) Alternative dynamic regimes and trophic control of plant succession. Ecosystems 9:659-672

Shorohova E, Kuuluvainen T, Kangur A, Jogiste K (2009) Natural stand structures, disturbance regimes and successional dynamics in the Eurasian boreal forests: a review with special reference to Russian studies. Ann For Sci 66:201

Siedlecka A, Roberts D (1992) The bedrock geology of Varanger Peninsula, Finnmark, North Norway: an excursion guide. Geological Survey of Norway special publication, vol. 5. Geological Survey of Norway, NGU

Sochava AV, Siedlecka A (1997) Major element geochemistry of Neoproterozoic succession of Varanger Peninsula, North Norway, and Sredni and Rybachi Peninsulas, Northwest Kola, Russia: provenance patterns and basin evolution. Geol Surv Norw Bull 432:77-93

Sørensen LI, Mikola J, Kytoviita MM, Olofsson J (2009) Trampling and spatial heterogeneity explain decomposer abundances in a sub-arctic grassland subjected to simulated reindeer grazing. Ecosystems 12:830-842

Speed JDM, Cooper EJ, Jonsdottir IS, van der Wal R, Woodin SJ (2010) Plant community properties predict vegetation resilience to herbivore disturbance in the Arctic. J Ecol 98:1002-1013

Stark S, Tuomi J, Strommer R, Helle T (2003) Non-parallel changes in soil microbial carbon and nitrogen dynamics due to reindeer grazing in northern boreal forests. Ecography 26:51-59

Tenow O (1972) The outbreaks of Oporinia autumnata Bkh. and Operopthera spp. (Lep., Geometridae) in the Scandinavian mountain chain and Northern Finland 1862-1968. Zool Bidr Upps 2(Suppl):1-107

Tenow O, Bylund H (2000) Recovery of a Betula pubescens forest in northern Sweden after severe defoliation by Epirrita autumnata. J Veg Sci 11:855-862

Tenow O, Bylund H, Karlsson PS, Hoogesteger J (2004) Rejuvenation of a mountain birch forest by an Epirrita autumnata (Lepidoptera: geometridae) outbreak. Acta Oecol 25:43-52

Tomback DF, Achuff P (2010) Blister rust and western forest biodiversity: ecology, values and outlook for white pines. For Pathol 40:186-225

Tybirk K, et al. (2000) Nordic Empetrum dominated ecosystems: function and susceptibility to environmental changes. Ambio 29:90-97

van der Wal R (2006) Do herbivores cause habitat degradation or vegetation state transition? Evidence from the tundra. Oikos 114:177-186

van der Wal R, Brooker R, Cooper E, Langvatn R (2001) Differential effects of reindeer on high Arctic lichens. J Veg Sci 12:705-710

Vanbergen AJ, Raymond B, Pearce ISK, Watt AD, Hails RS, Hartley SE (2003) Host shifting by Operophtera brumata into novel environments leads to population differentiation in life-history traits. Ecol Entomol 28:604-612

Väre H (2001) Mountain birch taxonomy and floristics of mountain birch woodlands. In: Wielgolaski FE (ed) Mountain birch forest ecosystems, vol 27. UNESCO, Paris, pp 35-46

Virtanen R, Pöyhtäri P, Oksanen L (1999) Topographic and altitudinal patterns of heath vegetation on Vannøya and the northern Varanger Peninsula, northern Norway. Acta Bot Fenn 167:3-28

Wardle DA, Zackrisson O, Hornberg G, Gallet C (1997) The influence of island area on ecosystem properties. Science 277:1296-1299

Wardle DA, Yeates GW, Barker GM, Bellingham PJ, Bonner KI, Williamson WM (2003) Island biology and ecosystem functioning in epiphytic soil communities. Science 301:1717-1720

Wielgolaski FE (ed) (2001) Mountain birch forest ecosystems. UNESCO, Paris

Wookey PA, et al. (2009) Ecosystem feedbacks and cascade processes: understanding their role in the responses of Arctic and alpine ecosystems to environmental change. Glob Change Biol 15:1153-1172

Zackrisson O, Nilsson MC, Steijlen I, Hornberg G (1995) Regeneration pulses and climate vegetation interactions in nonpyrogenic boreal Scots pine stands. J Ecol 83:469-483

Zackrisson O, Nilsson MC, Wardle DA (1996) Key ecological function of charcoal from wildfire in the Boreal forest. Oikos 77:10-19

Zimov SA (2005) Pleistocene park: return of the mammoth's ecosystem. Science 308:796-798 